\title{
EL OCASO DE LA CLAUSURA: MUJERES, RELIGIÓN Y ESTADO NACIONAL. EL CASO CHILENO**
}

\begin{abstract}
RESUMEN
La decadencia del modelo religioso femenino representado por los conventos de monjas contemplativas, entre fines del XVIII y la primera mitad del siglo XIX, es parte de un proceso de reforma propia del despotismo ilustrado, del liberalismo de los estados nacionales y también, en el caso chileno que aquí se estudia, del reformismo eclesiástico. Este artículo sugiere que las monjas contemplativas dejaron de ser mujeres para el liberalismo, por no cumplir su rol de madres, y en el catolicismo fueron desplazadas por las religiosas de vida activa, que eran un modelo de religiosas en el mundo que cumplían roles de madres sociales. La exclusión de las mujeres de los derechos políticos está vinculada con este proceso, en cuanto la formación del nuevo espacio público requería la formación de un espacio privado gobernado por madres. Este artículo estudia las tres etapas del reformismo ilustrado, del liberal y del religioso en el caso chileno.
\end{abstract}

Palabras clave: conventos de clausura; modelo normativo femenino; formación del Estado liberal; reformismos eclesiástico siglo XIX.

\section{ABSTRACT}

The decline of the women religious model represented by contemplative nun convents between the end of the eighteenth century and the first half of the nineteenth, was part of a reform process experienced in different spheres of influence. Among them it is possible to mention the enlightened despotism, the liberalism exerted by National States and the ecclesiastical reformism of Chile. This article shows that contemplative nuns stopped being considered as women for liberalism because they did not fulfill a mother role. Moreover they were displaced within the Catholic realm by religious women with active roles in society, who fulfilled the role of social mothers. The exclusion of women from the enjoyment of political rights was linked to this process because the formation

* Doctora en Historia. Pontificia Universidad Católica de Chile. Correo electrónico: sserrano@uc.cl

** Agradezco a mi alumna M. Josefina Silva Santa Cruz su enorme contribución a este trabajo, así como agradezco las facilidades brindadas por el Archivo del Arzobispado de Santiago. 
of a new public space required the conformation of a private space governed by mothers.

Key words: Cloister Convent; Feminine Normative Model; Liberal State Formation; Ecclesiastical Reformism Nineteenth Century.

Fecha de recepción: mayo de 2009

Fecha de aceptación: octubre de 2009

\section{LAS MONJAS, ¿SON MUJERES ${ }^{1}$}

Las monjas, sin duda, fueron mujeres en la sociedad de Antiguo Régimen, en aquellas monarquías católicas cuyo fundamento de legitimidad política era religioso. En esa sociedad donde ambas esferas tenían espacios de autonomía interdependientes, el papel de las religiosas en monasterios tenía un estatuto no solo legítimo sino altamente legitimado. Religiosamente eran las vírgenes esposas de Cristo consagradas a la oración, para Su mayor gloria, para su salvación y para la salvación de tantos, incluidos los gobernantes, por medio de sus plegarias. Políticamente formaban un cuerpo dentro de los estamentos de la sociedad protegido por el derecho eclesiástico y común. Dependían de la monarquía y de la jerarquía eclesiástica, mientras su gobierno interior era corporativo y jerárquico. Dependían sobre todo de sus reglas y constituciones, frente a las que comprometían sus votos solemnes. Los conventos eran también una sociabilidad femenina con múltiples redes con el exterior. Eran un asilo en su sentido primigenio, es decir, un lugar inviolable, que por serlo otorgaba protección. ¿Protección de qué? Para unas, protección de algún tipo de deshonra, de la pobreza, del abandono o de la vejez; para otras, protección para mantener los equilibrios económicos, sucesorios y de prestigio de sus familias; para todas, protección de "la calle", como decía una monja chilena, del mundo que sustraía del espacio sagrado. Por estas legitimidades -y no al contrario-, eran también centros de cierto poder económico debido a dotes y legados. En una cultura de unanimidad cristiana, devota de María, ellas eran mujeres, vírgenes y esposas.

Las sospechas, desde la perspectiva política que aquí nos importa, se iniciaron con las monarquías ilustradas y el golpe de gracia vino con la fundación de las repúblicas, con la secularización del fundamento de legitimidad política que significaba la soberanía popular. Este cambio, queremos argumentar, significó la invisibilidad de los monasterios femeninos. Las monjas dejaron de ser mujeres, porque en esa nueva sociedad el rol político de las mujeres era asumir plenamente su condición de madres. Su invisibilidad no reside en que fueran monjas, sino en el modelo femenino religioso que encarnaban. Estas monjas, las de clausura, las

1 Este artículo debe mucho a la reflexión de Elisa Cárdenas en "La construcción de un orden laico en México y las 'señoras religiosas' o ¿se pueden secularizar las monjas?”, en María Pilar Gutiérrez Lorenzo (coord.), Cuadernos de Investigación histórica 1, Guadalajara, Universidad de Guadalajara, 2008, 203-222. 
contemplativas, eran esposas místicas, un modelo femenino que todavía atraía a muchas mujeres en el siglo XVIII americano, mientras en el europeo comenzaba a decaer, pero que no era el modelo pertinente ni deseado. Tanto es así, que el problema no residía en que fueran monjas, sino en que a su lado se levantaba otro modelo, que ahora habrá que llamar con rigor religiosas consagradas de vida apostólica. Estas fueron el nuevo modelo de mujer católica porque eran "madres", porque enseñaban a las madres carnales a serlo seriamente y eran las madres adoptivas de quienes no las tenían en un sentido material o normativo. Esta es la secularización en sentido femenino, equivalente a la que en el clero masculino fue el paso de las órdenes regulares al clero secular. Pero en su versión femenina no fueron las religiosas contemplativas las que se transformaron en apostólicas. En ellas cambió el modelo. El cambio de modelo consagrado no es una metáfora aunque también pueda serlo- de la relación entre las mujeres y la religión en el siglo XIX en la Europa católica o en América, es un cambio, queremos proponer, sustantivo del nuevo orden político.

Junto con sustraer a las religiosas contemplativas de su condición femenina, el Estado las atacó o las hizo invisibles. La Iglesia jerárquica las protegió, las controló y las siguió considerando un modelo religioso, pero se le hicieron más borrosas, porque ante la ruptura de la unanimidad católica, ante la secularización entendida ahora como separación de esferas, se necesitaban madres consagradas en el mundo. Se hicieron nocivas, inviables o borrosas para los grandes poderes.

¿Será por ello mismo que han sido invisibles para la historiografía política de este período? Más aún, ¿cómo explicar que hayan sido invisibles para la historiografía feminista que ha discutido la marginación de las mujeres en el nuevo espacio público y su reclusión al espacio privado? ¿Será, acaso, porque para la historiografía feminista como para el Estado liberal, las monjas contemplativas tampoco eran mujeres?

El debate historiográfico en torno a las mujeres y la Revolución Francesa ha sido rico y bastante conocido ${ }^{2}$. Joan Landes sostuvo que la Revolución había sido un retroceso para las mujeres, pues, a pesar de su participación, las confinó a un espacio privado doméstico más restringido todavía que en la sociedad anterior. La república se construyó con la intención deliberada de sacar a las mujeres de la esfera pública. Joan Scott ha sostenido, por su parte, la incompatibilidad intrínseca entre feminismo y teoría liberal, mientras Lynn Hunt sitúa la marginación de la mujer de los derechos políticos en la incierta construcción del individuo autónomo y libre, más que en la

\footnotetext{
2 Joan B. Landes, Woman and the Public Sphere in the Age of the French Revolution, London and New York, Cornell University Press, 1988; Lynn Hunt, The Family Romance of the French Revolution, Berkeley, University of California Press, 1992; Peter Jones, The French Revolution in Social and Political Perspective, London, Arnold, 1996; Joan Wallach Scott, "French Feminists and the Rights of 'Man': Olympe de Gouge's Declarations"; y Dale Van Kley, "Church, State, and the Ideological Origins of the French Revolution: The Debate over the General Assembly of the Gallican Clergy in 1765", en Ronald Schechter (ed.), The French Revolution, Massachusetts, Oxford, Blackwell Publishers, 2001, 210-235 y 263-300; Lynn Hunt, "The many bodies of Maria Antoinette: Political pornography and the problem of the feminine in the French Revolution"; y Olwen Hufton, "In search of Counter-Revolutionary Women" en Gary Kates (ed.), The French Revolution. Recent Debates and New Controversies, New York, Routledge, 2001, 279-301 y 302-333.
} 
teoría liberal en sí misma. La exclusión de las mujeres no se entiende tanto en el problema de igualdad versus diferencias, cuanto en la reorientación sutil respecto de la familia y del rol de la mujer en la Revolución. En este debate que aquí solo se esboza, se discute sobre las mujeres jacobinas que pidieron la participación y cuyos clubes fueron suprimidos, pero no se ha visto su contracara, otras organizaciones femeninas que también fueron suprimidas en los mismos años, como los conventos femeninos. No están porque no se les considera parte de la historia política ${ }^{3}$. Y en eso se equivocan, porque los conventos femeninos fueron suprimidos por razones análogas, a la larga, a aquellas por las cuales las mujeres no ingresaron a la ciudadanía política. Dicho de otra manera, en el concordato de 1808 entre Napoleón y la Santa Sede, las congregaciones femeninas de vida activa, las hospitalarias, fueron autorizadas, mientras que las contemplativas fueron prohibidas. Estas monjas -no todas las monjas- fueron suprimidas no solo por ser cuerpos de manos muertas, ni siquiera por ser cuerpos en sí mismos, sino porque eran inútiles en su condición de mujeres. Ellas, igual que las jacobinas, igual que todas las mujeres, debían ser madres. La formación del espacio público, ya lo sabemos, requiere la formación de un espacio privado como condición y como contraparte. Esto no era intrínseco a la teoría liberal sino una rígida barrera, como señala Pierre Rosanvallon, entre el espacio contractual de la sociedad civil y el universo orgánico de la familia ${ }^{4}$. Las monjas eran mujeres y porque lo eran siguieron el destino no solo de otras corporaciones religiosas, sino el de las mujeres y el de las mujeres católicas.

El ocaso de la clausura, entonces, es más que el final de un período. Es el inicio de otro, aquel en que el espacio público redefine la relación entre mujer y religión.

\section{LA SOSPECHA MONÁRQUICA Y EL APOYO DIOCESANO}

El ingenioso historiador liberal chileno de la segunda mitad del siglo XIX, Benjamín Vicuña Mackenna, se refirió a los conventos como esos "chalets místicos"5. Su incisiva definición es una herencia de cómo fueron vistos por la

3 Ulrike Strasser, State of Virginity: Gender, Religion, and Politics in Early Modern Catholic State, Ann Arbor, The University of Michigan Press, 2004, 1-24.

4 Pierre Rosanvallon, Le sacre du citoyen. Histoire du suffrage universal en France, París, Éditions Gallimard, 1992, 128.

5 Citado en Carlos Peña Otaegui, Una Crónica Conventual: el Monasterio de las Agustinas de Santiago. 1574-1951, Santiago de Chile, El Imparcial, 1951, 44. La bibliografía sobre los conventos chilenos se refiere casi exclusivamente al período colonial: Juan de Guernica, Historia del Monasterio de las Clarisas de Nuestra Señora de la Victoria, Santiago [s.n.], 1944; Gaspar Cardemil, "Los monasterios coloniales de Chile": Revista Católica tomo XIX, Santiago de Chile 1910; Reinaldo Muñoz Olave, Las Monjas Trinitarias de Concepción. 1570-1822, Santiago de Chile, Imprenta San José, 1918; Luis Francisco Prieto, Crónica del Monasterio de Capuchinas, Santiago de Chile, Imprenta San José, 1911; Arturo Fontecilla Larraín, "Recuerdos del Antiguo Monasterio de las Monjas Capuchinas", en Boletín de la Academia Chilena de Historia 27, Santiago de Chile, 1943, 77-93; Úrsula Suárez, Relación autobiográfica. 1666-1749, Santiago de Chile, Academia Chilena de la Historia, 1987; Marcela Krause Bisquertt, Monasterios femeninos en el reino de Chile, Tesis de Licenciatura, Pontificia Universidad Católica de Chile, Santiago de Chile 1995; Raissa Kordic Riquelme (ed.), Epistolario de sor Dolores Peña y Lillo. Chile, 1763-1769, Madrid, Universidad de Navarra, Ed. Iberoamericana, 2008; Carmelitas Descalzas del Monasterio de San Rafael, El Arca de 
monarquía ilustrada y por el liberalismo regalista republicano. También, con ciertos matices, por el reformismo eclesiástico. Desde mediados del siglo XVIII los conventos femeninos han sido descritos desde la normativa tridentina, que repuso e impuso sistemáticamente el cumplimiento de la clausura monástica. Frente a ese ideal, muchos conventos en el siglo XVI europeo y en el XVIII español y americano fueron vistos como anómalos, pues el mundo se introducía en el convento. Ello dista de ser una mirada analítica, como lo ha mostrado la bibliografía reciente para América Latina sobre el período virreinal ${ }^{6}$. El catolicismo latinoamericano que nació junto a la Reforma y se construyó a partir del Concilio de Trento no fue tridentino en más de un sentido. Los conventos femeninos no tenían muchas razones para serlo. Las monjas en su definición rigurosa, para llamar así a las benedictinas, las cistercienses y varias otras que eran monásticas -por algo se llaman así- no pasaron a América ni tampoco su versión masculina. Pasó el modelo de las órdenes mendicantes, porque era tierra de misiones donde se requería evangelizar más que contemplar. Los mendicantes, teniendo votos perpetuos y clausura, salían al exterior para ejercer funciones pastorales. El convento femenino americano, en su práctica, tenía el vínculo inverso: era el mundo el que cruzaba sus puertas y en ese sentido cumplían una misión equivalente. A ellas raramente se les vio en las calles, de hecho las únicas ocasiones en que formaban parte del ceremonial público, con procesiones, clero, sagradas religiones y pueblo, arcos de flores y cortejo de calesas, era cuando una comunidad iba a fundar una nueva y era recibida por la ciudad. Fue el caso de cinco monjas capuchinas que en 1745 partieron de Santiago a fundar su monasterio en Buenos Aires ${ }^{7}$. El día que ingresaban al convento había un convite que también era público.

La separación drástica entre lo sagrado y lo profano posiblemente no tenía sentido en aquella sociedad. Es cierto que entre los siete conventos existentes en la ciudad de Santiago de Chile durante el período colonial, la observancia de la regla admitía diferencias, siendo las agustinas, las clarisas y las de Santa Rosa menos contemplativas que las carmelitas y capuchinas, que formaban una comunidad pequeña sin más seglares que las sirvientas 8 . "El convento en aquella edad", dice el

tres llaves. Crónica del Monasterio de Carmelitas Descalzas de San José. 1690-1990, Santiago de Chile, 1989.

6 Asuncion Lavrin, Brides of Christ: Conventual Life in Colonial Mexico, Stanford University Press, California, 2008; John J. Clunes, Cuban Convents in the Age of Enlightened Reform 1761-1807, Gainesville, University Press of Florida, 2008; Stephanie L. Kirk, Convent life in Colonial Mexico: a Tale of Two Communities, Gainesville, University Press of Florida, 2007; Kathryn Burns, Colonial Habits. Convents and the Spiritual Economy of Cuzco Peru, Durham and London, Duke University Press, 1999.

7 Archivo del Arzobispado de Santiago (AAS), Fondo General (FG), Vol. 4, fjs. 214-315.

8 A fines del siglo XVII existían en Santiago los conventos de Las Agustinas (1574), de las Claras de Antigua Fundación (1604), Claras de la Victoria (1678), Carmen Alto de San José (1690) y el Beaterio de Santa Rosa (1680). Durante el siglo XVIII se fundó el convento de Capuchinas (1727), el Beaterio de Santa Rosa se transformó en convento de religiosas Dominicas (1754) y se fundó el de las Carmelitas de San Rafael (1770). En: La Provincia Eclesiástica Chilena, Erección de sus Obispados y División en Parroquias, Friburgo, Herder, 1895, 347-403. En este trabajo se estudian solo los conventos de Santiago, sin considerar el único que había en Concepción. Por la naturaleza del argumento que se quiere destacar, los conventos son tomados como un tipo que los reúne a todos. 
cronista franciscano sobre sus hermanas clarisas ya en el siglo XX, "era un mundo pequeño de oficinas diferenciadas por la clase de habitantes: religiosas, seglares, esclavas, educandas, negras y blancas". Con genuina inocencia agrega: "hoy no podemos imaginar aquella mezcla de personas en la Casa de Dios"9. Los reformadores de nuevo y viejo cuño dan a entender que las mujeres entraban por razones frívolas a ser servidas, como decía el mismo cronista. No era frivolidad. Es cierto que había un sector que no escogía entrar, aunque las fuentes dan muy escasa pista de ellas; es posible que no todas -es difícil saberlo- entraran por una vocación religiosa, pero ¿cómo diferenciar en aquella sociedad una vocación religiosa de una cultura religiosa que cruzaba transversalmente a la sociedad? En aquella sociedad el convento podía ser una opción, pero no la religión ${ }^{10}$. El convento era un espacio religioso de pertenencia corporativa, grupal, comunitaria y jerárquica, donde, por lo mismo, la obediencia era la contracara de la protección. Reproducir en su interior prácticas familiares en las celdas que cobijaban a un grupo formado por parientes, protegidas, educandas y sirvientas contradecía la vida comunitaria, que solo se mantenía en los oficios del coro. Las monjas mantenían un peculio propio además de la dote, que era comunitaria, cultivaban una sociabilidad, preferentemente pero no solo femenina, con pequeñas "fiestecitas" que a veces tenían sainetes y música, además de brasero, mate, galletas, dulces y hasta un poco de vino. Estas prácticas no hacían del convento un espacio poco religioso. Kathryne Burns sostiene con acierto que las monjas redefinen para ellas mismas las instituciones del matrimonio y de la familia ${ }^{11}$. Habría que agregar que reproducen dentro del convento la interfase entre lo sagrado y lo profano, propia de la sociedad en que se insertan. También en el mundo se expresaba con vigor el sentimiento religioso en contra de la norma. Las mujeres seglares se flagelaban en las procesiones de Semana Santa con trajes de penitentes, se disciplinaban con cruces sobre los hombros y no guardaban su lugar detrás de los hombres. El último sínodo chileno del período colonial insistió en su prohibición y no se extinguió por eso en el siglo siguiente, sino por cambios en la formas de piedad ${ }^{12}$. En América, la distinción iniciada en Europa entre conventos contemplativos y congregaciones apostólicas, que tímidamente se iniciaron con las Ursulinas en el siglo XVII, era ficticia. Permanecieron los conventos con una interpretación de la regla que, sin ser menos religiosa, la adaptaba a una sociedad distinta.

La monarquía y la jerarquía eclesiástica aspiraban a que Trento se encarnara en el Imperio. A lo largo del siglo XVII hubo intentos por reformar los conventos, pero sin la sistematicidad que adquirieron en el siglo siguiente, con incentivos religiosos,

9 De Guernica, op. cit., 77.

10 Charles Taylor, A Secular Age, Cambridge, Massachusetts, and London, The Belknap Press of Harvard University Press, 2007, 3 .

11 Burns, op. cit., 110.

12 Synodo diocesano, que celebró el Ilussimo. Doctor Don Manuel de Alday y Aspee, Obispo de Santiago de Chile, del Consejo de su Magestad, en la Iglesia Catedral de dicha ciudad: a que se dió principio el día quatro de Enero de mil setecientos setenta y tres años, Iglesia Católica, Arquidiócesis de Santiago, Lima, [s.n.], 1764, 214-215. 
económicos y también sociales ${ }^{13}$. Las reales cédulas para que los obispos informaran del estado de los conventos de sus diócesis y procuraran la observancia empezaron a llegar a comienzos del siglo XVIII al reino de Chile, donde los siete conventos dependían del diocesano, pues después de batallas que llegaron a ser campales, se resistieron a depender de los priores de la rama masculina de sus órdenes. Ello permitió obviar el conflicto jurisdiccional que se dio en otras partes de América ${ }^{14}$. Las órdenes de la Corona no eran solo genéricas, sino también específicas. En 1729 se ordenaba al Obispo que visitase el monasterio Antiguo de Santa Clara para la "reforma de los velos", orden que más tarde se extendió a los otros conventos sin mayores consecuencias, posiblemente porque el Obispo no consideraba que estuvieran en ninguna condición crítica. En 1757 el obispo Manuel de Alday, uno de los más destacados del siglo, riguroso en el gobierno eclesiástico, que enfrentó la debacle de la expulsión de los jesuitas y realizó el sínodo que seguiría vigente hasta fines del siglo XIX, defendió a su manera los conventos, en las visitas que realizó a petición del monarca. Sus ordenanzas coincidieron con la política central en dos problemas que acompañarían a los conventos por mucho tiempo: reducir las sirvientas y muchachas de educación y restringir la profesión de religiosas de velo negro mientras las rentas no pudieran sustentarlas. "El exceso que hay de religiosas ha ocasionado consiguientemente el de las sirvientas y niñas", señaló. Restringió la edad de las educandas a mayores de cinco años y mandó estrechar las rejas de los locutorios y restringir su horario. No se refirió, sin embargo, a los dos puntos neurálgicos que eran la vida común y el peculio propio. Celebró la educación de las niñas, necesaria para que fueran criadas en el temor de Dios, y concluyó: "en lo sustancial se profesa mucha virtud en este Monasterio"15. Al año siguiente evaluó que sus ordenanzas se estaban cumpliendo satisfactoriamente y que los conventos no requerían gran preocupación por parte de Su Majestad. Pero el Rey no estuvo de acuerdo con el Obispo. El fiscal del Consejo de Indias le había informado sobre el exceso de monjas y seglares en las Agustinas, donde todas vivían juntas, "originándose graves perjuicios a la quietud espiritual así como a las rentas"16. Allí se inició una política que continuaría el reformismo eclesiástico: reducir la comunidad. Reflejando el espíritu político borbónico, sentó su concepción del patronato, pues si el Obispo no cumplía sus órdenes intervendría el presidente de la Real Audiencia ${ }^{17}$. El Obispo procedió a pedir informes a cada convento y un notario de la Audiencia certificó las cuentas entregadas por el síndico, pero insistió en que él había hecho las reformas necesarias: que cada religiosa no pudiera tener más de dos criadas y que no hubiera más de cuatro en una celda, solo dos seglares por religiosa y que no se recibiesen menores de cinco años.

13 Susan Miden Socolow, The woman of Colonial Latinamerica, Cambridge, Cambridge University Press, 2000, 100; Anne Staples, "Un balance histórico: el papel de los conventos mexicanos de monjas, siglo XIX", en Manuel Ramos Medina (coord.), Memoria del I Coloquio Historia de la Iglesia en el siglo XIX, México, Condumex, 1998, 199-216.

14 De Guernica, op. cit., 70-74; Diego Barros Arana, Historia jeneral de Chile, Santiago de Chile, Rafael Jover, 1884-1902, V: 316-322 y 328-335.

15 AAS, FG, Vol. 4, fj. 6. Las de velo negro debían disminuir de 60 a 50 y 32 las de velo blanco.

16 Idem.

17 Ibid., fj. 222. 
"De modo [concluía], que reforme de modo posible el exceso que antes había en estos puntos y de resulta de la nueva visita que he practicado no halle conveniente poner mayor estrechez, porque este número de criadas y seglares no causa inconveniente grave; pues el que algunas falten al silencio se corrige prontamente y lo sería [...] exponer esas personas que allí viven cristianamente a los peligros que en el siglo le ocasionaría su pobreza ni puede privarse a las religiosas que las tengan para que de esta suerte logren el socorro de algunas cosas que no sufraga el monasterio fuera de la manutención precisa, y cuya falta tal vez pudiera dar mérito a que se quebrantase la observancia en los puntos más esenciales, que se guarda muy regular en ese monasterio"18.

Alday no negó que había reformas necesarias, pero defendió el tipo de convivencia interna del convento y el uso del peculio propio. No consideraba que hubiera falta notable, pues se practicaban los votos, la práctica sacramental era frecuente y se hacían ejercicios piadosos, "para el mejor servicio y agrado de Dios al que aspiran"19. En 1759 otra real cédula volvió sobre la reforma y Alday defendió que el tamaño fuera acorde con las rentas, respaldando así el informe emitido por la priora del convento de Santa Rosa ${ }^{20}$. El siglo siguió en la misma línea, revisando minuciosamente las finanzas de los conventos, incluido el costo de los géneros para hábitos. Hacia fines de siglo el objetivo de reducir el número de religiosas y de seglares se mantuvo y en 1797 se instruyó una inspección anual de los conventos en toda América ${ }^{21}$. Aun así, Alday impuso su criterio en lo sustancial, porque las comunidades no disminuyeron como la monarquía pretendía. El Obispo claramente mantuvo una visión más benévola sobre los conventos que la monarquía. El título decimosexto de su Sínodo prohibió en los conventos femeninos las visitas frecuentes y su prolongación después del Ave María, cuando debía cerrarse el locutorio, todo lo cual "aunque se observa" era recomendable recordarlo nuevamente. Así, "las esposas de Jesucristo, con el retiro, logren el trato familiar de su Esposo" 22 . Criticó, finalmente, lo mismo que criticaba a las mujeres del mundo: la falta de modestia en el vestuario y en los convites para el día de ingreso, una austeridad que parecía un imperativo más femenino que religioso.

La benévola mirada diocesana, que duró hasta que el reformismo regalista tomara en sus manos la construcción del nuevo estado independiente, revela que el "chalet místico" en cierto sentido no era ninguna ironía, sino una expresión de la

18 Ibid., fj. 24. Las Agustinas señalaron una cifra bastante menor que las informadas por el fiscal al Consejo de Indias: 66 de velo negro, de las cuales 32 cumplían algún oficio, y 44 de velo blanco, encargadas de horno panadería y cocina. Las de velo blanco que entregaban alguna dote eran campaneras de confesiones, enfermeras menores, cantoras, sacristanas menores u hortelanas.

19 Ibid., fj. 235.

20 Ibid., fj. 150. Alday impuso su criterio, pues según ese mismo informe, en 1786, en las Agustinas había 52 religiosas de velo negro y 40 de velo blanco.

21 Ibid., fjs. 264-265. Las políticas regalistas de Carlos III afectaron el corazón de la vida religiosa de la capitanía general con la expulsión de los jesuitas, pero las medidas expropiatorias de comienzos de siglo que afectaron conventos y cofradías no se cumplieron en Chile, en parte porque apenas alcanzaron a llegar, en parte porque era un territorio demasiado pobre.

22 Synodo diocesano..., op. cit., 219. 
cultura religiosa que no se explica por la brecha entre la norma y la práctica, sino más bien por la reunión indisoluble de lo sagrado y lo profano. La ruptura que vendría tomó su tiempo, fue larga y llevó a los conventos a una verdadera clausura no solo religiosa, que era la que se buscaba, sino social y cultural.

\section{LAS RELIGIOSAS DE LAS MANOS MUERTAS}

Las independencias hispanoamericanas, al contrario de la Revolución Francesa, no tuvieron un carácter anticatólico hasta varias décadas más tarde, especialmente en México y en Colombia. Francois Furet señaló en sus primeros escritos sobre la Revolución Francesa que su anticatolicismo no le era intrínseco, sino que devino en parte por la supresión de los derechos feudales y en parte por las necesidades financieras detrás del secuestro de los bienes eclesiásticos y del rechazo a cualquier otro poder por sobre su soberanía, es decir, Roma. La constitución civil del clero, sigue Furet, no pretendía destruir a la Iglesia, sino poner el orden religioso en línea con el poder civil. Allí la Iglesia y la Revolución se enfrentarían irrevocablemente. Era una consecuencia de la "reconstrucción radical del cuerpo político en base a principios universales"23. Las órdenes religiosas eran corporaciones al interior de la Iglesia, figura jurídica que devenía extraña. La Asamblea Legislativa de 1790 autorizó la exclaustración y le negó reconocimiento a los votos monásticos. Aun dentro de la tradición galicana, en que los reyes habían intervenido en reformas religiosas, parte del clero francés y Roma consideraron que era una intervención inaceptable del poder temporal en asuntos espirituales.

La soberanía indivisible de la nación, fuente única de la ley, fue el principio que guió los procesos de laicización de los estados católicos y que se concretó a través de experiencias políticas bien diversas. El caso de Chile fue de negociación. No se cerraron conventos, a las órdenes regulares se les expropiaron los bienes para luego devolvérselos y a los conventos femeninos se les dejó decaer. Los primeros gobiernos republicanos se sitúan dentro del reformismo religioso de carácter regalista, más que de una investida liberal. Se dejaron espacios jurídicos y políticos para que la propia jerarquía eclesiástica llevara a cabo las reformas. Ello no le restó pasión al conflicto, pero sin duda violencia. Por tanto, nos interesa mirar ese primer reformismo civil que llamaremos regalista, para estudiar luego el reformismo eclesiástico.

Como se mencionó anteriormente, la sospecha frente a los conventos había sido más de la monarquía que de la Iglesia y de la sociedad local. En ellas eran un centro suficientemente sensible de opinión como para que, en esos meses en que se discutía si las provincias de ultramar dependían del monarca cautivo luego de la invasión francesa a España o de la Junta Central primero y del Consejo de Regencia en 1810, circulara el rumor de que si se formaba una Junta de Gobierno los conventos femeninos serían expropiados y suprimidos. Literalmente el día antes de la declaración de la Junta de Gobierno, el recién nombrado gobernador, el

23 Francois Furet, The French Revolution, Oxford, Blackwell Publishers, 1992, 84. 
conde de la Conquista Mateo de Toro y Zambrano, que era objeto de presiones para convocar un cabildo abierto que proclamara una Junta de Gobierno, envió una misiva a las prioras de los conventos femeninos que revelaba el fantasma francés. Algunos "ignorantes y sediciosos", escribía, habían pretendido persuadirlas de que los vecinos nobles de la capital alterarían la vida religiosa de los monasterios, confiscarían sus propiedades y podrían "cometer otros excesos dignos de la más severa animadversión" si se nombraba una Junta. El Conde les pedía que denunciaran al gobierno a esos ignorantes y sediciosos que las oprimían con "semejantes novedades" y les prometió que, "en caso de instalarse algún congreso para conservar estos dominios al S. Dn. Fernando Séptimo, lejos de innovarse alguna cosa en los Monasterios, las Personas de Vuestras Reverencias, sus propiedades, serán respetadas y defendidas por la fuerza pública"24.

El Conde tuvo razón, el congreso efectivamente se formó y no tomó medidas contra los conventos, salvo algunas que indicaban la dirección de los tiempos: en 1811 decretó que las dotes de las religiosas fallecidas debían ser devueltas a las familias, con la consiguiente descapitalización, y en 1812 ordenó que los conventos femeninos abrieran escuelas para niñas ${ }^{25}$. Ninguno tuvo efecto en un momento incierto, que terminó en 1814 con la recuperación española de la Capitanía General de Chile. De todas formas, la Independencia afectó a los conventos. Algunos edificios fueron confiscados para el uso de los ejércitos, se les exigió erogar sumas en metálico para financiar las guerras, unos fueron sindicados de realistas y otros de patriotas y fueron prisión de mujeres de ambos bandos, así como lugares de ocultamiento.

La política, que había irrumpido de pronto en la ciudad, irrumpió también en los conventos igual que antes, pero ahora con apremio y desconcierto. Hubo tensión entre los lazos familiares de las religiosas, la mayoría pertenecientes a familias patriotas, y la dependencia y lealtad al Prelado, que en sus primeros momentos fue un destacado realista. La política los comprendía a todos, también a las mujeres, quienes en el proceso de Independencia participaron de una forma más directa y activa de lo que la galería de las mujeres célebres trasunta. No solo las afectó por motivos familiares y los devastamientos de la guerra, sino que participaron políticamente, teniendo alguna influencia en la opinión pública. El Monitor Araucano, órgano de gobierno en la Patria Vieja, decía con elocuencia:

"Nos equivocamos: el influjo no está reservado a los que sufragan en las Asambleas del pueblo, o se acercan al gobierno. Estas oradoras del sarracenismo inoculan sus ideas a los domésticos; estos las extienden a sus corresponsales; a cada referencia se añade alguna novedad, que al fin reunidas con otras componen un todo de imposturas degradantes" 26 .

24 AAS, FG, Vol. 4, fj. 280.

25 Silva Cotapos, Historia eclesiástica de Chile, Santiago de Chile, Imprenta San José, 1925, 185; Prieto, op . cit., 21.

26 Tania Mella Lizana, Las mujeres en la Independencia de Chile: Acciones y contribuciones, Tesis de Licenciatura, Universidad de Chile, Santiago, 2004. 
Se culpó a los curas, como se haría a lo largo del siglo, de la mala influencia sobre las mujeres y de estas sobre sus dependientes. Las mujeres participaron como correos y como espías, y desde un bando y otro fueron sentenciadas por delito de sedición de lesa majestad con la cárcel, con el secuestro de sus bienes o incluso, aunque pocas, con la pena de muerte. "Mi sexo no me dispensa de las obligaciones de chilena para luchar en contra de la tiranía", decía una detenida ${ }^{27}$. El ser sujetos de delitos políticos y de obligaciones fiscales, como pagar contribuciones sobre sus propiedades o donativos obligatorios al gobierno, no tuvo relación alguna con los derechos políticos. Luego del triunfo patriota y la declaración definitiva de la Independencia en 1817, varias mujeres recibieron honores y la prensa las llamó "virtuosas ciudadanas".

Los nuevos estados hispanoamericanos se consideraron herederos del patronato regio, a la vez que ninguno expulsó al catolicismo del Estado. Ello significaba construir unas relaciones directas con Roma, en un período en que Roma apoyaba a España en cuanto monarquía católica y no había reconocido las independencias. Cada país resolvió esta relación de manera particular, pero en todos hubo un momento en que las autoridades eclesiásticas, que tenían importantes poderes jurisdiccionales, no estaban nombradas canónicamente, sino por las autoridades civiles que tomaron en sus manos las reformas religiosas. Chile había tratado sin éxito de encontrar un arreglo con Roma, por lo cual el Director Supremo ejerció de hecho el patronato para decretar que los religiosos no anduvieran en las calles de noche, para "que se corte de raíz tan pernicioso abuso", y que las patrullas los entregaran a sus prelados para ser $\operatorname{castigados}^{28}$. Y tomó medidas de mayor envergadura, como autorizar al diocesano para arbitrar en los conflictos de las órdenes regulares. La directriz de la política del período no era nueva ni original, solo que ahora era republicana: el clero debía ser útil a la Iglesia y al Estado y debía contribuir con sus bienes en caso de urgencia ${ }^{29}$.

"El clero es sostenido y defendido por la sociedad [decía el periódico oficial], y en recompensa el instruye a la sociedad, administra el culto y presenta sus oraciones al Ser Supremo. Sin embargo aun debe más; es que en una necesidad urgente y notoria de la Patria, ha de contribuir también a las cargas públicas siempre que no alcancen las fuerzas de los demás ciudadanos" 30 .

En la década del 20, los gobiernos y parlamentos quisieron uniformar el pensamiento político del clero e iniciar la tan consabida reforma de las órdenes regulares, que incluyó a los conventos femeninos en lo concerniente a acreditar la práctica de la observancia de su orden como requisito para profesar y hacerlo

27 Idem

28 Decreto 22 mayo 1818, en Archivo Bernardo O'Higgins (ABO), tomo XI, Santiago de Chile, 1952, 55 .

29 Gazeta Ministerial de Chile, 24 de julio de 1819, en $A B O$, tomo XIII, Santiago de Chile, 1858, 30.

30 Gazeta Ministerial de Chile, 25 de diciembre de 1819, en ibid., 237. 
después de los 25 años ${ }^{31}$. "No conviene", sostuvo el Senado, "que el hombre enajene su libertad en edad en que no le es lícito enajenar sus bienes" y, ahondando en un juicio que solo podía hacerse desde la valoración de la libertad individual, recordaba: "es preciso no olvidarse que la profesión antes de los 25 años tiene a nuestros conventos y monasterios llenos de individuos descontentos, arrepentidos, sin provecho y quizás próximos a su desesperación"32. Este fue el preámbulo a la discusión sobre la secularización de los bienes del clero, que se dio en el contexto de la venida de una delegación apostólica -la Misión Muzzi-, pedida por el gobierno chileno con la esperanza de encontrar un acuerdo para que Roma aprobara el patronato $^{33}$. Estos años, entre 1822 y 1824 , fueron prolíficos en el debate sobre el sentido de los conventos. Fue un momento esencialmente anticlerical $-\mathrm{y}$ por lo mismo, como ha señalado Roberto di Stefano- también religioso. La crítica era bastante universal: el clero regular era ignorante, fomentaba la superstición, sus costumbres eran relajadas, sus riquezas eran muertas y eran inútiles para la religión y el Estado. Aparecieron múltiples pasquines que expresaban ese anticlericalismo a través del humor, la diatriba o el sarcasmo, a la vez que discutían la jurisdicción del Obispo para secularizar a los regulares y transformar sus bienes en congruas. Entonces apareció el primer periódico propiamente católico El Observador Eclesiástico (1823), escrito por un dominico, Fray Tadeo Silva, con el objeto de defender la autonomía de la autoridad eclesiástica para realizar una reforma, partiendo de la base de que la reforma era necesaria. Inmediatamente apareció su opositor directo, que por cierto se llamó El Liberal. Estos dos periódicos, de no más de cuatro páginas y que no duraron más de un año, tienen la importancia de reflejar el debate político religioso de ese momento tan crucial como incierto.

El Liberal defendió directamente la supresión de los conventos y la secularización de sus bienes, criticó que las órdenes fueran cuerpos con inmunidades, con fondos estancados en manos muertas, con propiedades que entorpecían el desarrollo urbano y cuyos capitales debían contribuir al progreso de la educación, la agricultura, el crédito y el aumento de la población. "Con despojar a mil hombres que dicen que aman la pobreza, se puede enriquecer a un millón que la detestan" 34 . Las órdenes eran gravosas para el Estado, porque no contribuían a su conservación y eran mantenidas por vivos y muertos. Ello permitía expropiar sus bienes, porque la propiedad de los cuerpos regulares o monacales pende de la ley, que no abdica de la defensa del bien común cuando se le perjudica. La

31 Sesiones de los Cuerpos Lejislativos de la República de Chile (1811-1845), Santiago de Chile [s.n.], 1886-1908, Senado Conservador, $N^{\circ}$ 235, 21 de mayo de 1823; Barros Arana, op. cit., XIV:100; Claudia Castillo, "Una propiedad sin vida. Secularización de los bienes de regulares en Chile (17671842)", en Nicolás Cruz e Iván Jaksic (eds.), Seminario Simon Collier 2005, Santiago de Chile, Pontificia Universidad Católica de Chile, Instituto de Historia, 2005, 11-41.

32 Barros Arana, op. cit., XIV:101.

33 Carlos Oviedo Cavada, "El viaje de Juan María Mastai Ferreti a Chile (Pío IX)”, en Historia 1, Santiago de Chile, 1961, 205-284: 257; Ricardo Krebs, La Iglesia en América Latina en el siglo XIX, Santiago de Chile, Ediciones Universidad Católica, 2002, 79.

34 El Liberal, $\mathrm{N}^{\circ} 3,15$ de agosto de 1823, en Colección de antiguos periódicos chilenos (CAPCh), Santiago de Chile, Ediciones de la Biblioteca Nacional, 1965, 9-342:15. 
autoridad citada era evidentemente el Conde de Campomanes ${ }^{35}$. La propiedad de los regulares no lo era a título personal, sino derivada de sus funciones. No era privada, se sostenía, porque no era enajenable. Políticamente los regulares eran nulos, no eran ciudadanos, no defendían a la república con las armas, no eran electores ni elegidos. El problema de fondo era la permanencia de los cuerpos:

"La nación goza de un extenso imperio sobre todos los cuerpos que existen en su seno y si ella no tiene derecho para destruir el cuerpo entero del clero porque es esencialmente necesario al culto de la religión, puede ciertamente destruir las agregaciones particulares de este cuerpo cuando las crea perniciosas o simplemente inútiles" 36 .

La expropiación se llevó a cabo en 1824, en un momento de inestabilidad política interna, de una guerra externa contra España por la independencia de Perú y de una pésima relación con Roma, pues Muzzi no aceptó el patronato y el gobierno le pidió que se fuera. Más aún, la expropiación no produjo ninguno de los resultados esperados, principalmente porque faltaron compradores ${ }^{37}$. Fue, sin embargo, una importante medida política que la monarquía no había podido realizar y que la república regalista enfrentó con reforzada convicción anticorporativa, dando su apoyo al clero secular y diocesano por su efectivo servicio religioso ${ }^{38}$.

¿Qué pasaba en estas condiciones con las mujeres consagradas? Lo más elocuente es su casi total ausencia en el debate y las medidas. La prensa reformista se mofó de las beatas, recalcó la inutilidad de estas religiosas que no vivían la observancia y un poema revelador y previsible dedicó a ellas uno solo de sus versos:

¿Cuál hace que las esposas

Abandones a sus hijuelos,

Y los dejen por los suelos

Por ser devotas ociosas?"39.

El poema era una crítica a todas las mujeres devotas, las consagradas y las seglares que no se hacían cargo de ser madres. El periódico católico, por su parte, les dedicó a las monjas un solo artículo para defenderlas: la filosofía del siglo solo veía en ellas mujeres privadas de su libertad, víctimas consumidas por el arrepentimiento o entes inútiles posiblemente perjudiciales a la población del estado. Los impíos no podían entender la felicidad que había en ellas, como lo

35 Ibid., 28.

36 Ibid., 211.

37 Barros Arana, op. cit., XIV:370 y ss., 409 y ss.; Boletín de Leyes y Decretos del Gobierno (BLD), Tomo I, Libro II, N ${ }^{\circ}$ 5, 6 de septiembre de 1824, Valparaíso, 1845, 238-240; Castillo, op. cit., 13.

38 Roberto Di Stefano, El púlpito y la plaza, Buenos Aires, Siglo Veintiuno, 2004, 156.

39 El Liberal, $\mathrm{N}^{\circ} 2,6$ de agosto de 1823 , en CAPCh, 1965, 19. 
demostraban las experiencias extranjeras, en que muy pocas salieron cuando les abrieron la clausura, y las muchas que pasaron a la clandestinidad allí donde los conventos fueron clausurados. El redactor conocía bien a las religiosas, porque era confesor de muchas de ellas, y en eso no se equivocaba. Pero tenía que probar más, explicó que eran útiles a la República por sus plegarias y que las "funciones mujeriles" que se les exigían ellas las cumplían al interior del convento, protegiendo niñas pobres y educándolas en los deberes de su sexo sin gravamen para el Estado. Si eran gravosas porque no se casaban, entonces lo eran igual a las se quedaban solteras ${ }^{40}$.

La argumentación de Silva es bastante lúcida, a nuestro juicio, porque muestra o define parte del sentido que los conventos tenían para esa sociedad, incluyendo a los liberales. De hecho, la crítica fue leve y no se tomaron medidas que las afectaran. Hay varias explicaciones posibles. Los conventos femeninos no eran suficientemente ricos como para ser apetecibles; los vínculos familiares con la élite criolla masculina eran estrechos, al contrario de los regulares, como lo señaló el sacerdote italiano secretario de Muzzi, Juan María Mastai: "El clero secular goza de gran estima en la ciudad, como también los monasterios de monjas"41. Los regulares, en cambio, eran muy mal vistos, según el mismo testigo. Ello confirmaría que este desprecio ideológico desde la normativa reformista conviviera con una cierta aceptación y hasta aprecio por el espacio de equilibrio y protección que esa institución entregaba al mundo femenino y, por ello, a la sociedad. En cambio en otros procesos de reforma religiosa fueron afectadas, como en Buenos Aires, que en esos mismos años abrió la clausura. En todo este período, finalmente se tomaron dos medidas que expresaban las críticas: la apertura de escuelas y la prohibición de profesar antes de los 25 años, como una forma de mantener el principio de la libre elección, de la voluntad personal y de la libertad individual. Ninguna de las dos, sin embargo, se cumplió a cabalidad. Las religiosas las rechazaron y dos décadas después el gobierno conservador, que ya había logrado sofocar muchos de los focos de conflicto a partir del triunfo de la batalla de Lircay en 1829 , volvió a la carga.

Es necesario resaltar que la llamada República Conservadora (1830-1861) mantuvo en la Constitución de 1833 el carácter católico del Estado, con prohibición de culto público de cualquier otra confesión; mantuvo el patronato, así como el recurso de fuerza y el fuero eclesiástico, además de las funciones civiles que desempeñaba el clero y el financiamiento estatal. Diego Portales, el tan famoso ministro al cual se le atribuye mucho de la construcción política de este período, era pragmático en materias religiosas: construyó acuerdos, partiendo por la devolución de los bienes secuestrados, y llegó a un entendimiento con Roma para el nombramiento de obispos. Sintomáticamente, el ministro que había firmado los decretos de reforma de 1823, Mariano Egaña, y quien no era precisamente un liberal, fue quien trajo a colación esas medidas dos décadas después, en 1846.

40 El Observador Eclesiástico, № 20, 3 de noviembre de 1823, en CAPCh, 1963, 355-361.

41 Oviedo Cavada, op. cit., 247. 
Mariano Egaña, como ministro de Justicia, Educación y Culto, tuvo una política de apoyo a las instituciones religiosas de beneficencia y de educación. Justificó la devolución de los bienes del clero en que la doctrina y la moral religiosa eran la base de la instrucción pública abocada a la educación del pueblo. Esos eran los servicios a los que debían entregarse los religiosos. Se trataba de la defensa de la utilidad moral y la función social de la religión que había defendido fuertemente el redactor del Código Civil francés, Portalis, una referencia relevante para los juristas chilenos ${ }^{42}$. Era en ese sentido que la religión debía secularizarse, es decir, que la ley civil estuviera por sobre la religiosa y que la religión se sometiera a la sociedad y a su transformación en un sentido ilustrado ${ }^{43}$. Sin embargo, dada la relación política y religiosa del gobierno conservador con la Iglesia Católica y la defensa de ambos de la mantención del orden, difícilmente podía pensarse en una reforma violenta. Las medidas reformistas fueron tímidas, tanto así que se volvió al mismo problema de la década de los 20 sobre la edad permitida para profesar. La Constitución del 33 había fijado la edad de 25 años para ser ciudadano elector y 21 si se era casado; el código civil que se promulgaría en 1856, y que en ese momento estudiaba una comisión presidida por Andrés Bello, cambió las edades del matrimonio apartándose del derecho canónico, derecho que siguió vigente en materias religiosas. Si el derecho canónico había establecido como edad mínima 12 años para las mujeres y 14 para los hombres, el Código la subió a 25 para ambos sexos sin autorización paterna ${ }^{44}$. En ese marco, el gobierno volvió a decretar en 1847 que la profesión de perpetuo monaquismo requería como mínimo 25 años. Las excepciones para el caso femenino son elocuentes: los monasterios de mujeres, dice el decreto, y es posiblemente la primera vez que se las llama de esa manera, que asistían enfermos o enseñaban podían profesar a los 22, y a los 20 para los votos temporales. En el caso de las mujeres, era su utilidad la que definía la racionalidad del acto de profesar y la edad de profesar defendía la libertad individual en relación a la autoridad paterna ${ }^{45}$.

El silencio en torno a las religiosas de manos muertas, en cualquier sentido del término, fue abrupto y solitariamente roto por el diputado Fernando Urízar Garfias, regalista y filojansenista, quien propuso lisa y llanamente la supresión de los monasterios femeninos. Evocando el caso francés, rescató a las hospitalarias y enseñantes, que se habían conservado en tiempos de trastornos políticos y religiosos. El argumento no era en absoluto original, lo original residía en que se

42 Portalis veía a las religiosas antiguas reducidas a una vida común sin horizonte y Napoleón no tenía inconvenientes en que las antiguas vivieran la vida común hasta el final de sus vidas, pero que no tuvieran noviciados ni usaran públicamente sus hábitos. Claude Langlois, Le catholicisme au féminin: Les congrégations françaises à supérieure générale au XIXe siècle, París, Les Éditions du Cerf, 1984, 70 .

43 Michel Rapaport et al., Religion et culture en Europe. 1800-1914, París, Éditions Atlande Neuilly, 2001, 102.

44 Francisca Rengifo Streeter, Un recurso de protección femenina: el divorcio eclesiástico en Santiago de Chile, 1850-1890, Tesis Doctoral, Pontificia Universidad Catolica de Chile, Santiago de Chile, 2008, 40-41.

$45 B L D, 12$ de marzo de 1847 , Libro $\mathrm{XV}, \mathrm{N}^{\circ} 3$. Las excepciones se referían a rebajar la edad de acuerdo a los grados de estudios o a la utilidad de sus funciones, como ser misionero entre infieles. 
presentó en el hemiciclo parlamentario y fue ampliamente reproducido por la prensa. Las contemplativas, señalaba, no retribuían a la sociedad la protección que esta les daba, eran inútiles, vivían separadas del mundo quizás contra su voluntad, seguramente en la desesperación, mientras que en el mundo serían edificantes. En fin, los conventos tenían el "tétrico aspecto de una reclusión forzada" 46 . Su proyecto de ley prohibía la fundación de conventos contemplativos y suprimía los votos perpetuos en los ya existentes, haciéndolos temporales por tres años. Si la edad, entonces, era una forma de autonomía de posibles dependencias, especialmente la paterna, se agregaba la temporalidad de los votos, que significaba la imposibilidad de enajenar la libertad individual. Es posible que aquí se encuentre el paso de la crítica ilustrada a la crítica liberal. ¿Se podía abdicar de derechos inherentes en el régimen jurídico? El arzobispo de Santiago Rafael Valentín Valdivieso, un avezado jurista, respondió en la Revista Católica, posiblemente su único pronunciamiento público sobre las religiosas contemplativas. Su primera línea de defensa fue teológica y la segunda fue constitucional, haciendo valer la unión de la Iglesia y el Estado, pero la más interesante para nuestro argumento fue la jurídica-política. En nombre de la libertad, sostuvo, los reformadores la coartaban, contraviniendo los fueros de la conciencia y de la libertad civil. Si bien la sociedad tenía derecho a autorizar la fundación de cualquier establecimiento, lo hacía en forma particular y no genérica. El Estado solo podía prohibir aquello que consideraba intrínsecamente malo para la sociedad. Suprimir los cuerpos monásticos contradecía la tendencia de las libertades modernas.

“Podría la autoridad pública impedir que algunas mujeres se reuniesen para meditar y orar, ligándose del modo que quisiesen, con tal solo que no perturbasen el orden establecido? [...] Mientras cumpla con estas condiciones cada cual es libre de disponer de su persona como le agrade. Esta libertad no es concesión de la ley, sino antecedente y anterior a ella" 47 .

Esbozó el argumento con que se quiso enfrentar al laicismo durante todo el siglo, al sostener que los derechos de la Iglesia eran anteriores a los del Estado. "La omnipotencia legislativa", concluyó, "es la peor de cuantas tiranías pueden afligir a la humanidad porque mata la libertad con sus propias armas". Sería un abuso descontextualizar este argumento y mostrar a Valdivieso como un liberal anglosajón. Solo quisiera destacar que esta línea de argumentación entre Urízar y Valdivieso es la que marca el paso, la que cruza la frontera de la crítica ilustrada a la crítica liberal. No se trata solo de si las monjas eran útiles sino también de si eran libres y, si lo eran, si es que podían enajenar voluntariamente esa libertad.

Sin embargo, ese era un debate que todavía no destruía la confesionalidad del Estado. En los hechos, las monjas no solo no fueron suprimidas sino que, de

46 Sesiones del Congreso Nacional, Cámara de Diputados, N $^{\circ}$ 2, 2 de junio de 1847, Santiago de Chile, 1846.

47 Revista Católica, No 126,11 de junio 1847, 597-600. 
acuerdo al Código Civil, el derecho canónico fue incorporado al derecho nacional en materias de culto. Con ello, las monjas contemplativas siguieron dependiendo del prelado y del síndico que las representaba en los asuntos jurídicos. Los conventos estuvieron totalmente protegidos por la ley. Eso hace al caso chileno muy distinto al francés o al mexicano. Sin embargo, y aquí viene el otro gran tema que plantea el estudio de los monasterios femeninos, si el Estado no se involucró fue en buena medida porque esa reforma la quería hacer la propia Iglesia. La Iglesia no era ajena, porque no podía ni quería, a una sociedad donde los cuerpos y estamentos se desvanecían y donde la secularización imponía una separación, también dentro de la religión, del espacio sagrado y el profano. El Arzobispo entró a los conventos sin mayores conflictos de competencia jurisdiccional, a establecer la vida común y la observancia de la regla. Si el Estado liberal no veía a las contemplativas, la jerarquía eclesiástica las vio con cariño pero con temor, no las hizo invisibles, pero sí, en cierto sentido, borrosas.

\section{EL REFORMISMO ECLESIÁSTICO GOLPEA LOS MUROS}

Los monasterios femeninos chilenos, ya lo mencionamos, eran diversos entre sí en cuanto a la observancia de la regla y también al interior de ellos había religiosas más proclives al cambio que otras. En la década de 1830, una abadesa agustina recién elegida propuso al obispo Manuel Vicuña introducir la observancia, por el trastorno que producía la entrada y salida de seglares y sirvientas. La extensa respuesta de su superior indica claramente que la reforma eclesiástica desde arriba no había madurado. Su reflexión está más cerca del obispo Alday, de la segunda mitad del siglo XVIII, que de su sucesor una década más tarde. A Vicuña, "las circunstancias, el espíritu del siglo, la experiencia" le indicaban que esa reforma no era posible.

"Yo tiemblo cuando considero las consecuencias que podría traer, los obstáculos que habría que vencer, las discordias y disensiones que esto podría acarrear, los fundados recelos, de que prevaleciesen de esta variación los interesados en la apertura de la Calle para renovar sus ataques y pretensiones [...] y sobre todo me hace mirar como inverificable el proyecto los gastos necesarios para mantener una comunidad de 70 monjas y 50 criadas [...] fuera de las de coro y otras que por su edad no sería posible tirarlas a la calle después de haber servido".

Vicuña se extiende largamente en la dificultad de centralizar oficios, servicios y provisiones que funcionaban como pequeños grupos con recursos diversificados, “[...] porque si a las monjas no se les proporciona todo, todo, no hay vida común. Y para todo esto, ¿cuánto se necesita?”. Fueran o no acertadas las reflexiones de economía doméstica del Obispo, las cuentas no daban para la vida común. Vicuña insistió en que esa población heterogénea podía convivir religiosamente si las monjas guardaban su propia virtud y admitían seglares circunspectas. Frente a la desigualdad de los recursos internos que reclamaba la abadesa, el Obispo sostuvo 
que no era la igualdad de la vida común lo que se requería, sino darle a cada una lo necesario. En fin, defendió el viejo esquema por todas estas razones y también por el papel protector del convento, como una obra de caridad que protegía "a tantas niñas desamparadas; a tantas pobres cuyas almas escapan tal vez de la eterna perdición, proporcionándoles asilo". No era el momento de entrar en "novedades" 48 .

Las fuentes no esclarecen en forma directa la manera en que la reforma de los monasterios femeninos volvió a la agenda episcopal. Pero sin duda estuvo vinculada a la gigantesca organización que inició Rafael Valentín Valdivieso como arzobispo de Santiago, a partir 1845. El sí era un reformador tridentino, prudente, político, pero no por ello menos decidido a disciplinar la vida eclesiástica. Valdivieso tenía razones doctrinarias y también políticas para imponer la disciplina interna para enfrentar las críticas liberales. También tenía poder político para hacerlo, porque Roma, con el apoyo del gobierno, le otorgó competencia sobre las órdenes regulares. La reforma obedece a una coyuntura crucial en que un gobierno conservador y regalista y una curia conservadora e incipientemente ultramontana comparten su necesidad.

Valdivieso retomó las peticiones para abrazar la vida común que algunas religiosas habían hecho a su antecesor, pidiendo que cada monja le hiciera ver su parecer directa y privadamente ${ }^{49}$. Casi todas lo hicieron por escrito, aunque posiblemente las de velo blanco lo hicieron personalmente en sus frecuentes visitas. En el caso de las Agustinas, de 81 religiosas, solo dos rehusaron. La vida común era vivir

“comiendo, vistiendo, curándose todas las religiosas de los fondos comunes conforme lo previene su santa regla, satisfaciéndose todas las necesidades del dicho fondo común, sin que sea permitido a alguna en particular usar de renta, peculio, o contribución voluntaria o contribución forzosa proveniente de bienes reservados, donados o en cualquier otra forma [...]"50.

Junto a una comisión de capellanes y la consulta a las abadesas, la primera medida fue separar a las seglares y sirvientas en distintos departamentos. Valdivieso envió una misiva a cada abadesa con las nuevas medidas, que fue leída en comunidad. Fue un momento de confusión y de conflicto, que permite avizorar las complejidades de ese mundo.

En primer lugar, la información entre el exterior y el interior de los muros era tan estrecha que el rumor de la separación de religiosas y seglares se supo antes de que la comunicación fuera leída y despertó alarma entre las seglares, temerosas de ser expulsadas.

48 AAS, FG, Vol. 4, fjs. 300-301, sin fecha.

49 "Reforma de regulares", en Boletín Eclesiástico, Tomo I, Libro III, No 29, 30 de marzo de 1846, Santiago de Chile, 1859, 232-239.

$50 \quad$ Ibid., $\mathrm{N}^{\mathrm{o}} 37,10$ de octubre de 1846, 247. 
"Como no ha sido posible ocultar del secularismo la aspiración de las religiosas sobre la vida común, le relataba la abadesa Agustina al prelado, al otro día mismo que esto entendieron sin que se les dijese que se fuesen, llamaron muchas de sus casas o conocidas [...] contando y dando ya por hecho lo que ni las mismas religiosas sabían [...] y al mismo tiempo disponiéndose para salir sin que se les dijese una sola expresión de salida. Es preciso pues que V.I. sepa ya que hay en el monasterio entre las seculares dos clases de personas, unas que están por su voluntad y que por ningún motivo saldrían del monasterio, y otras contra su voluntad, y que se toman de cualquiera insignificante expresión para tratar de salida sin que se encuentre medio de poder hacer que semejantes personas dentren [sic] en razón" 51.

Al rumor externo se sumó la duda interna. Para la agustina Josefa Vial, que llevaba 30 años en el convento donde señalaba haber sido muy feliz, con la reforma "muy pronto tocaremos los efectos fatales de la decadencia". La comunidad no sería capaz de llevarla a cabo y, "aunque mis luces y capacidades sea a la vista muy corta", quería cumplir con su conciencia ante Dios de decirle a su Obispo, con la "santa libertad que debe ser el carácter de quien habla con su razón”, que el espíritu religioso estaba deteriorado y que la reforma no resultaría ${ }^{52}$. El cambio en realidad trastornaba la forma de convivencia, pues significaba sacar a las seglares de las celdas, instalarlas en nuevos dormitorios que eran más pequeños, más incómodos y más solitarios; significaba una nueva forma de convivencia entre las monjas, con la construcción de refectorios, cocinas, lavanderías y ropería común. La nueva arquitectura significaba otra sociabilidad, creaba otros vínculos que rompían un tejido antiguo. Por ello la aceptación fue evidentemente ambigua y su aplicación no fue lineal. Las celdas las mantuvieron quienes las habitaban, pero la titularidad tendió a no renovarse y el Obispo no autorizó que se vendieran cada vez que una abadesa se lo pidió para aumentar las $\operatorname{arcas}^{53}$. Las seglares seguían conviviendo con las monjas, había visitas y sainetes en las celdas. Las medidas generales se fueron contraviniendo casuísticamente, pidiendo muchísimas autorizaciones para prácticas que antes eran usuales, como la venta de celdas ya mencionada, recibir pensiones desde el exterior o autorizar el ingreso de religiosas mayores ${ }^{54}$. La persistencia de prácticas antiguas producía conflictos entre las partidarias de la reforma, las que la entendían en forma laxa o las que directamente la rechazaban. Una religiosa que informaba de estos avatares al Obispo le pedía que cortara estas ambigüedades con las seglares.

"Si V.I. no manda que se le ponga puerta a dicho departamento jamás podrá haber el buen arreglo que necesitamos para nuestra paz interior [...] También

51 AAS, FG, Vol. 136, fjs. 32-36.

52 Ibid., fj. 192-193.

53 Ibid., Vol. 126, fj. 57.

54 Ibid., Vol. 136, fj. 21: "pues la costumbre que cerca de esto ha sido que solo con la licencia de la abadesa pudiesen las religiosas recibir sus mesadas tanto ellas como la de las seglares y las limosnas que mensualmente les asignaban". 
rogamos que a las monjas que cuidan del departamento no se les lleva comida de la cocina de comunidad sino que coman en primera mesa en su departamento y enseguida coman las seglares. Y no se dé licencia para que vengan señoras a prestar servicios o a dormir a este lado con el pretexto que acompañan a las (hijas?) [...]"55.

La reforma, como muestran las oposiciones, estaba en marcha. La abadesa agustina, con gran solemnidad y complacencia de su alma, informaba al Obispo que el dos de enero de 1858 la comunidad comería junta por primera vez en el refectorio. Los informes de la priora de Santa Rosa indicaban que si antes no había más de cuatro monjas en el coro, ahora había 16. En el refectorio se comía la misma comida y en la ropería se guardaba toda la ropa, todo lo cual se hacía antes en las celdas. Los hábitos empezaban a usar las mismas varas de género, casi todas se habían rapado la cabeza y muchas habían entregado sus pertenencias a la procuradora. "Todo esto se lo pongo para su consuelo y vea todo lo que se ha conseguido en tan pocos meses lo que en otras partes en años no los consiguen" Pero el curso de la reforma no era tan idílico. Varias religiosas se resistieron a comer en el refectorio, porque no tenía alacera, brasero, ni agua, porque todo estaba muy lejos dentro del convento y requería mucha fuerza para el acarreo. Si no se invertían unos 20.000 pesos, decía posteriormente la misma priora, "todo lo antiguo volverá a las celdas", ella había perdido toda autoridad y "no sabía qué hacer" 57 .

La reforma transformó las relaciones de poder, afirmando el control del prelado. Las relaciones jerárquicas antiguas se hicieron más rígidas y horizontales. En los inicios algunas abadesas resintieron el nuevo control. La abadesa de las Clarisas de la Victoria, Ana María Morandé, en parte por su orgullo aristocrático, en parte por carácter, fue la única que se enfrentó al Obispo y llegó hasta decirle que "la falta de simpatía que últimamente me observa, no la toma en consideración nuestra regla" 58 . La costumbre era que las abadesas informaran al Obispo, mientras que ahora debían pedir su autorización. El Obispo efectivamente ejerció su autoridad en el convento. Es el cambio que muestra el paso de un cuerpo jerárquico relativamente autónomo a uno centralizado. En esto, los monasterios femeninos siguieron el mismo destino de las corporaciones de Antiguo Régimen, ya fuera con respecto al Estado o a la jerarquía eclesiástica. Las abadesas fueron asumiendo el nuevo estilo con desconcierto, haciendo gala de obediencia, pero reiterando peticiones que indicaban la persistencia de las prácticas ${ }^{59}$. Una de las más sensibles para las monjas fue la mantención de sus confesores. La costumbre era que la abadesa enviaba una lista para que el prelado los nombrara, pero ahora debían

55 Ibid., fj. 204.

56 Ibid., Vol. 130, fj. 300

57 Ibid., fjs. 300-301.

58 Ibid., Vol. 126, fj. 164.

59 Debido al sobrepoblamiento del convento y al cuidado que requerían las ancianas, Valdivieso fue inflexible en que no entrara ninguna mayor de 30 años. Mientras la ley procuraba que no entraran jóvenes, la reforma procuraba que no entraran mayores. 
aceptar el nombramiento de confesores ordinarios. Posiblemente ese fue uno de los cambios más difíciles para religiosas y seglares, pues los confesores eran fuente de información y de protección espiritual y mundana. De hecho, muchos de ellos fueron aliados con las religiosas en la oposición a la reforma y a la centralización del poder episcopal. Los confesores eran unos "operadores" en muchas de las disensiones internas y externas.

"Para que no se confundan nuestros caprichos con la voluntad de Dios, [le señaló el Obispo a la abadesa Morandé cuando le envió la tabla de confesores en 1848] es preciso atendamos a las reglas de la Santa Iglesia. Estas previenen que no sean las monjas sino los obispos quienes designen los confesores. Si pues estos repugnan designar a unos y la monja insiste, claro está que no es la voluntad de Dios sino la de la monja la que tal cosa inspira" 00 .

La correspondencia de monjas rogando al Obispo que se les designe el confesor querido, arguyendo aflicción, tormento y estado de pecado, demuestra cuán sensible y relevante era el vínculo personal en la práctica religiosa. Algo semejante sucedía con el nombramiento de capellanes, en que la abadesa dejó de intervenir. En 1847 la abadesa de la Victoria le hizo llegar al Obispo la renuncia que por escrito le había entregado el capellán, sugiriéndole que la aceptara y con la proposición de nombres para reemplazarlo. Valdivieso consideró que era una intromisión en una decisión que solo le correspondía a él, no admitió la renuncia y le reprochó su petición con dureza. Ante ello la abadesa le respondió: “[...] no me he gobernado nunca por pasión, ni mirado respetos humanos, he obrado siempre con libertad de espíritu, mirando solo a Dios [...] y el haberme gobernado de otro modo en la ocasión presente sería haber hecho contra mi conciencia"61. Ella quiso manifestar también su autoridad frente al Obispo: si el capellán era tan santo como indicaba, entonces que la sacara a ella. Pero el Obispo impuso su autoridad, porque el convento estaba dividido y el capellán había conspirado en contra de la abadesa a través de sus confesadas.

El establecimiento de una autoridad centralizada y jerárquica buscaba también extirpar las fuentes de poder en los conventos, como la de los confesores, los capellanes y muy especialmente de las familias de la élite, que por razones económicas y de parentesco los sentían como suyos. En este aspecto, el poder central reforzó la autoridad de la abadesa para cortar ese vínculo. Un caso muy revelador fue el de Francisco Ignacio Ossa, síndico del pacífico convento de las Capuchinas, que era no solo uno de los hombres más ricos de la capital, sino también un piadoso colaborador en múltiples corporaciones religiosas de beneficencia, mayordomo de varias cofradías y benefactor del propio convento. Cuando quiso visitar a su hija novicia con toda la familia a una hora

$60 \quad$ Ibid., fj. 275.

61 Ibid., fjs. 6-7. Era el tipo de conflicto de gobierno que la reforma producía, pues en realidad el convento se había dividido y el capellán había intervenido muy directamente, ejerciendo influencia a través de sus confesadas. 
desacostumbrada, el capellán lo autorizó, pero la abadesa se opuso. “Ay, Señor, qué trabajo es que entren ricas a los monasterios", fue su comentario al Obispo ${ }^{62}$. Una noche intempestivamente entró al convento el cuñado de la novicia Ossa para sacarla. La abadesa se opuso y consultó de inmediato al provisor, quien le respondió lacónicamente que el Obispo no se opondría porque de todas formas iba a salir. La abadesa, que no estaba enterada de esta situación, no autorizó la salida y aunque denunció una conspiración entre la familia y el capellán, la novicia igualmente salió. Los procedimientos fueron todos indebidos y el Obispo, aunque le dio su apoyo, tampoco pudo evitarlo ${ }^{63}$. Así, se multiplican los casos de miembros de familias prominentes de la capital para entrar o sacar a sus parientes por temporadas, siempre que fueran seglares o novicias, o presionar para que la comunidad votara a favor del ingreso de una hija como novicia, y aunque el interlocutor para las familias solía ser el Obispo y no la abadesa, ella también tenía sus atribuciones. "Mas nos importa la paz de nuestra comunidad que un millón de pesos que nos diera, pues menos falta con qué comer" ${ }^{24}$. Las familias suponían reciprocidad y en cierta forma la exigían, si además de la dote refaccionaban las celdas, daban mesadas y propinas a sus parientes religiosas. "Sabemos ciertamente que ellas [las propinas] han sido causa de la crítica y mofa que se ha hecho en algunas casas de nosotros hasta llegar a decir un padre que su hija religiosa había sido la polilla de su casa a causa de los gastos que le había ocasionado en su ingreso a la religión" ${ }^{65}$. El Obispo apoyó a las abadesas, pero la dependencia real de los conventos era mayor con las familias que con la jerarquía eclesiástica. Por ello la reforma fue tan estricta en disminuir la población de los conventos, para que vivieran de su propio patrimonio y ganaran su autonomía.

Jurídicamente, la reforma quedó complementada con el decreto que instauró la vida común en el Monasterio de las Claras de Antigua Fundación, en 1862. El cambio demoró, sin embargo, casi todo el siglo y solo se consolidó con el recambio generacional, a través de los noviciados. Para ese entonces, para cuando la reforma estuvo consumada, los monasterios eran visibles a los ojos de Dios, borrosos a los ojos de la Iglesia jerárquica y enteramente invisibles para el Estado. Con la reforma de los monasterios femeninos muere el único cuerpo femenino de Antiguo Régimen absorbido por el poder central.

\section{UN CUERPO ATRIBULADO}

Los conventos siempre tuvieron conflictos internos, pero la reforma agudizó las disensiones y abrió las puertas de la curia arzobispal para resolverlos. Los conventos eran instituciones jerárquicas, a la vez que igualitarias en su cúpula. Cuando la abadesa de Santa Rosa quiso transformar la arquitectura de su convento

\footnotetext{
62 Ibid., Vol. 136, fj. 372

63 Ibid., fj. 284.

64 Ibid., Vol. 130, fj. 69.

65 Ibid., fj. 342.
} 
consultando solo al consejo, las otras religiosas de votos solemnes reclamaron su marginación al Obispo. "Los años que llevo de religiosa me han dado a conocer que las monjas somos, como los niños, que cuando nos hacen parte de las cosas nos docilizamos con el mayor rendimiento y como que se toma a capricho el llevar adelante aquello en que se ha tenido parte", decía una de ellas ${ }^{66}$. El grupo reclamaba tener luces para distinguir lo que más convenía para el cumplimiento de la regla.

Los conventos tenían gobiernos corporativos. La máxima autoridad interna, la abadesa, era escogida por sus pares, las monjas de votos solemnes, y gobernaba en consulta con un consejo también elegido. Las seguían en la escala las hermanas de velo blanco, que hacían parte de los servicios de culto, con votos temporales y sin dote, y luego las sirvientas, encargadas del trabajo manual. La abadesa, que era escogida por tres años, ejercía un poder delegado, por lo cual su autoridad era débil frente a los conflictos internos entre grupos que a su vez hacían alianzas con los grupos subordinados. El poder residía en las monjas de velo negro, a quienes la abadesa debía tomar su parecer en muchas decisiones y, en las más importantes, acatar a la mayoría por medio de elecciones. Se votaba el ingreso de una nueva novicia y también su profesión. El convento, entonces, era una institución jerárquica, pero no centralizada en su gobierno. Las votaciones no eran meras formalidades, por el contrario, expresaban los conflictos del convento, en los cuales había presión y repercusión externa. Hubo ocasiones en que se votó a viva voz -fue el caso relativo a la profesión de una novicia- para que se supiera afuera quiénes eran las que habían estado en contra ${ }^{67}$.

Externamente la abadesa dependía del prelado, que canónicamente debía autorizar casi todas las medidas. El convento tenía espacios de autonomía y capacidad de negociación, dentro de una Iglesia que a su vez era un conjunto de cuerpos con distintas autoridades. Los conventos chilenos habían rehusado expresamente depender de las órdenes regulares masculinas, precisamente para esquivar su control. El prelado y la curia habían sido una autoridad arbitradora más que imperativa. Mediadora, porque el convento dependía menos de la jerarquía institucional que de la jerarquía sacramental del clero. La primera, mal que mal, la compartía con otras corporaciones religiosas, pero no así la sacramental. En esa dependencia las monjas eran como los seglares, con la diferencia de que los seglares, con sus cofradías, novenas, rosarios y procesiones, dependían menos del clero que una comunidad cuya práctica sacramental era parte de su esencia y por ello también frecuente. Así como hubo relaciones armoniosas con algunos capellanes y confesores, las hubo también conflictivas y muy conflictivas. La comunidad aceptaba la dependencia en lo dogmático y en lo jurídico, pero rechazaba que se inmiscuyeran en asuntos internos del convento. En los últimos días de la Colonia, el capellán de las Agustinas presentó un reclamo al Obispo por los servicios que no le eran

\footnotetext{
66 Ibid., Vol. 12, fjs. 19-20.
}

67 Ibid., Vol. 130, fj. 290. 
cancelados, entierros, misas rezadas a las de velo negro y las honras para seglares y sirvientes. Esto causó verdadera indignación en la abadesa, que lo acusó de ser ocioso y de descansar en el trabajo del sotacura, amenazando con no pagarle: "si no queremos, no lo haremos con [quien] nos quiere martirizar" 68 . El tono no tenía nada de sumiso. Ello contrasta con lo sucedido medio siglo después, cuando la abadesa capuchina se disculpó temerosa, ante la reprensión del Obispo por haberle sugerido un reemplazante del capellán porque dividía a la comunidad. Los capellanes eran personajes cruciales en el gobierno interno y la dependencia que más irritación y molestia causaba a las abadesas. La misma abadesa reclamaba, en 1858, no sentirse "obligada a rendirle vasallaje a una persona que tanto ha mortificado a esta pobre comunidad, y que si nos conformamos que goce esta capellanía es conociendo que N.S. quiere suframos esta cruz, pero que no tenga ninguna intervención en nuestra cosas [...]"69.

Tanto antes como durante la reforma, las religiosas resentían un cierto desdén con que las trataban las autoridades masculinas, así como ser piezas de poderes externos que no controlaban. En 1808, una abadesa le reclamaba al prelado que "algunas personas de afuera" circulaban rumores "con perjuicio nuestro, atendiéndose que por religiosas somos las más despreciables para su concepto, y que sin embargo de los conocimientos que no nos faltan, procuramos ejercitarnos en el continuo ejercicio de la paciencia". Solo "con nosotros", el Obispo postergaba sus decisiones y respuestas ${ }^{70}$. En 1852 otra abadesa sentía esa misma vulnerabilidad y pedía al Obispo que le diera mayor autoridad: "mis religiosas son muy buenas, no lo puedo negar pero cuando son inducidas por un sacerdote a conducirse de este modo, creen que hacen una obra santa, a esto se agrega nuestra ignorancia, para dejarse alucinar" 71 .

El gobierno corporativo -que de hecho sigue vigente en los monasterios- era viable en el consenso, pero era ineficaz para gobernar el disenso. Capellanes, confesores, votaciones, elecciones, uso de celdas y movimiento de seglares entre otros, fueron muchas veces motivo de conflictos internos que terminó resolviendo el Obispo. Las propias abadesas lo pidieron.

"Le suplico a su Señoría me escriba un mandato en el cual me ordene que no aigan [sic] mas sirvientes [...] porque mandándolo su Señoría puedo yo obrar con más libertad y la comunidad lo recibe bien como cosa dispuesta por su Señoría. Yo he consultado esto y me dicen que lo debo hacer así. Su Señoria dispensara todas mis molederas y disponga de su mas rendida súbdita"72.

Cuando en una votación de la comunidad agustina hubo algo así como un fraude, pues el número de votos no coincidió con el de electoras, la abadesa le

\footnotetext{
68 Ibid., Vol. 4, fj. 269.

69 Ibid., Vol. 136, fj. 298.

70 Ibid., Vol. 4, fj. 271.

71 Ibid., Vol. 136, fj. 300

72 Ibid., fj. 266.
} 
suplicó "a VSI me ordene lo que he de hacer"73. Otra le pedía que le hiciera "la gracia de venir un poquito, estoy afligida porque no entiendo bien lo que me dice"74. La tendencia del Obispo fue a fortalecer, aunque con precaución, el poder doméstico de la abadesa, especialmente en las votaciones para ingreso y profesión, en resistir presiones de las familias, en el ingreso de seglares parientes o en expulsar sirvientas que cometían desórdenes protegidas por otras religiosas. Esa protección era la reciprocidad a la obediencia que el Obispo exigió con rigor. Cuando la abadesa de Santa Rosa le hizo llegar una representación de varias profesas en apoyo a una petición, la nueva forma de gobierno desplegó su nuevo estilo. Ante la representación, Valdivieso tuvo una de las respuestas más duras que yo haya visto en su extensa correspondencia privada. Es una carta, por cierto, que no está en la minuciosa recopilación de sus escritos.

"Si el súbdito tiene dificultades para asumir lo que se manda, todo lo que puede hacer es manifestar con sumisión estas dificultades al superior [...] pero complotar a otros para que se sumen a los reclamos y, lo que es peor, constituirse en vocero para obligar mejor al Prelado es una indisciplina, un trastorno [...] En la Iglesia las cosas pasan de distinto modo que lo que ahora se usa en la sociedad civil. En esta se dice que la autoridad debe ejercerse a voluntad de los súbditos y en ella Dios ha colocado unos para mandar y otros para obedecer"75.

La abadesa no estaba apelando a la representación moderna sino a la antigua, y la referencia del Obispo revela ese choque. El orden corporativo de jerarquía colegiada estaba muy lejos de la representación igualitaria de la sociedad civil, pero la Iglesia, lo mismo que el Estado aunque con justificaciones distintas, buscaba afianzar su soberanía sobre los cuerpos.

Esta nueva forma de gobierno impuso relaciones más burocráticas allí donde habían sido y eran muy personales. La abadesa capuchina era prima del Arzobispo, la priora de Santa Rosa era hermana del secretario de la curia ("Mi Casimiro" encabeza todas sus cartas), prima de otro presbítero influyente de la Secretaría Arzobispal y el Arzobispo era su confesor. Los lazos de parentesco permitían una relación personal y epistolar estrecha y franca. La priora de Santa Rosa informaba a su hermano Casimiro sobre los capellanes y confesores obedientes al Prelado, para frenar la influencia de los regulares ${ }^{76}$. Sin embargo, las relaciones familiares no aseguraban un mayor apoyo a las abadesas y los vínculos tendieron a burocratizarse a favor de la jerarquía. La misma priora de Santa Rosa le pidió a su primo que interfiera a su favor frente a su hermano: "hágame el favor de decirle a Casimiro que porque se ha puesto tan durito conmigo, que nada de lo que le pido me concede [...]"77. Cuando la prima de Valdivieso le comunicó que los conflictos

Ibid., fj. 37.

Ibid., Vol. 127, fj. 26.

Ibid., Vol. 130, fj. 140

Ibid., Vol. 128, fj. 133.

Ibid., fj. 137. 
y divisiones dentro del convento eran en parte responsabilidad de la abadesa, su primo fue categórico: el orden residía en el respeto a quien manda ${ }^{78}$.

La burocratización de los vínculos significaba sobre todo imponer formas de administración que la Secretaría Arzobispal pudiera fiscalizar por razones económicas y jurídicas. Ello fue otro trastorno, porque las monjas no sabían hacerlo. Los asuntos patrimoniales los llevaba el síndico y los gastos domésticos eran autorizados por la abadesa, pero sin llevar una contabilidad. El gobierno doméstico del convento era de suyo complejo, por la enorme cantidad de servicios y por tanto de personal que lo circundaba. El hecho de ser mujeres y de clausura así lo requería: confesores, síndico, sotasíndico, director de obra y su mayordomo, médico sangrador, relojero, carpintero, albañiles, peones, serenos, sacristanes y proveedores de harina, legumbres y carne eran pagados en metálico. Como en todas las demás corporaciones religiosas, la curia pidió informe muy detallado de las cuentas diarias. "Las mujeres no somos tan expeditas como los hombres y esto atrasa", se defendía una de ellas ante las Cuentas Diocesanas. También en esto perdieron autonomía. La hermana de Casimiro Vargas, que por muchos años fue la persona "de pluma" de las preladas de su convento, le indicaba a su confesor y Arzobispo: "antiguamente como SSI recordara el modo con que se rendían antes las cuentas y como se rinden ahora, aquella libertad de las preladas para gastar y disponer de las platas como quieran". Ahora debía andar detrás de la prelada "para estar a cabo de los gastos y seguir los gastos y pagos que se hacen, salir al torno o locutorio [...] todo lo manejaban en este convento las preladas solas"79. La prelada siguiente volvió a la vieja usanza y se encontró con las Cuentas Diocesanas de la curia, que sencillamente no aceptó el extraño desorden. Las monjas tuvieron que aprender un nuevo oficio.

Gobernar la reforma fue un ejercicio complejísimo, que no bastaba en absoluto con la centralización del poder de la jerarquía, puesto que transformaba profundamente el rol social del monasterio, que residía en buena medida en esos vínculos internos que la reforma segregaba, vínculos de protección, de asilo, de cuidado a niñas y ancianas y vínculos religiosos de las consagradas entre sí y con las seglares. Una comunidad estrictamente de clausura tenía un sentido religioso radical que transformaba sus vínculos sociales.

Las seglares, al contrario de lo que puede creerse, también tenían un vínculo religioso. Residían en el convento en forma permanente, salían raramente con expresa autorización de la abadesa y consulta al Obispo. Era un grupo heterogéneo, por clase social, por edad, por motivación, relacionadas con alguna o algunas religiosas, que no solo eran protegidas sino que también protegían. La mayoría eran mujeres desamparadas protegidas por una monja en forma particular, con su peculio, en su celda. Algunas recibían limosnas del exterior y repartían sus sobrantes entre las religiosas más pobres. Otras vendían sus trabajos manuales. El peculio propio, con sus regulaciones -porque no era enteramente al arbitrio de las religiosas-, era también una forma en que las más ricas, las que tenían mesada fija

78 Ibid., Vol. 130, fjs. 310-311.

79 Ibid., Vol. 17, fj. 29. 
entre las religiosas, mantenían a veces con limosnas a veces con manutención, a las más pobres, a las de velo blanco y al resto. Esas mesadas provenían por lo general de las familias, lo cual era otra forma en que el convento dependía muy directamente del apoyo externo. Pero también sucedía a la inversa, que la comunidad como tal daba unas "pequeñas mesaditas" a las familias de las monjas, que según la priora de Santa Rosa en su mayoría eran pobres ${ }^{80}$. El convento era un centro de caridad hacia las seglares y hacia las familias pobres de las religiosas, que por la misma condición de serlo, eran familias pobres vergonzantes, es decir, que no lo eran de origen sino que se habían empobrecido. El convento manejaba un cierto excedente, cien pesos en el caso de este convento recién entrado a la vida común en 1862, que la priora pide licencia para repartir entre "distintas Señoras pobres de las mismas familias de las religiosas que se encuentran en suma pobreza" 81 . La vida común ya no permitía ese flujo y por ello pedía licencia para hacerlo con las rentas comunes del convento. "Quiebra el corazón”, decía la misma priora, "ver en tanta miseria a estas personas que en otros tiempos han tenido tantos bienes, y ahora hay veces que no tienen ni un pedazo de pan que darle a sus hijos; y a nosotros no nos falta"82.

La protección, al igual que el conflicto, comprendía a todas las mujeres del convento y se expresaba especialmente, como ya lo señaló Anne Staples para el caso mexicano, en el cuidado de las enfermas y de las ancianas, consideradas como tales pasados los 50 años. Por razones sencillamente demográficas -se entraba al convento para toda la vida y la mayoría estaba allí la mayor parte de su vida- la cantidad de mujeres enfermas o viejas que requerían cuidado era enorme. Por eso tanto las monjas de velo negro como el Obispo procuraron que las novicias fueran sanas y jóvenes, "[...] si pasa de 33 años por nada la admitimos", decía una priora. Las religiosas enfermas de velo negro eran cuidadas por las de la velo blanco o por sirvientas y seglares propias, que se quedaban con ellas por años de años y que no pocas veces aspiraban a su lugar cuando murieran. Curarse y morir en el convento era parte de la esencia de la vida comunitaria. "Todas nuestras antecesoras en todos tiempos se han resignado a sufrir sus dolencias por graves que sean y hasta la misma pérdida de la vida antes que abandonar nuestro santo retiro", sostenía la abadesa de Santa Clara cuando una religiosa pidió autorización a Roma para salir a curarse "a la calle", algo que nunca había sucedido en ninguno de los siete conventos de la capital, según aseguró.

"Hasta el mismo trance horrible de la muerte [...] se dulcifica con la compañía y preces de una Comunidad [...] si a esto se agrega el fervor y devoción con que se practican los sufragios [...] por cierto mucho más consoladores que los estériles aparatos que se hacen en el mundo, no puede menos que sernos más apetecibles pagar dentro de nuestra clausura el tributo necesario de la vida" 83 .

\footnotetext{
$80 \quad$ Ibid., Vol. 128, fj. 50.

81 Ibid., Vol. 127, fj. 16.

82 Idem.

83 Ibid., Vol. 33, fj. 11.
} 
Con la reforma, ese cuidado excluyó a las seglares separadas en sus propios departamentos, con lo cual adquirió un carácter de asilo, como sintomáticamente lo llamó una abadesa, que otras instituciones estaban asumiendo fuera del convento.

La vida común rompía los lazos ajenos a la regla, aunque fueran de caridad, como los llamaba una religiosa para justificarlos, pues eran finalmente temporales y no estrictamente religiosos. Mantener solo los vínculos de los votos significaba que las monjas de velo blanco debían hacer los servicios internos y las de velo negro cumplir la observancia, disminuir el tamaño de la comunidad y financiarla autónomamente. El ingreso de novicias se restringió y su tamaño debía ser permanente, de 21 en el caso de las carmelitas a 35 en el las agustinas. El tamaño de la comunidad no revelaba la demanda, pues estaba restringida. La renovación fue por lo tanto muy lenta y, aunque no tenemos los datos, el envejecimiento promedio debe haber sido alto. En el convento carmelita, que siempre observó la regla de mantener una comunidad con 21 religiosas con votos solemnes, en 1849 solo 10 de ellas estaban activas ${ }^{84}$. El ingreso dependió progresivamente del buen manejo de su capital, sobre todo de los réditos del capital cuyos deudores se hicieron cada vez más morosos. Los conventos no eran pobres ${ }^{85}$. El negocio inmobiliario y el valor de propiedades extensas en el centro de la ciudad fueron un salvavidas a sus finanzas hasta que finalmente, en el siglo XX, se mudaron a los suburbios de la ciudad.

La reforma del gobierno eclesiástico era un golpe vertical al gobierno horizontal de los conventos, era una muerte lenta de los cuerpos, como el gobierno liberal lo había hecho drásticamente con las otras formas corporativas, los claustros universitarios, los cabildos, los gremios, las cofradías y las órdenes religiosas. Salvo que en Chile, al igual que en otros países, esa reforma la hizo la jerarquía eclesiástica. Al final, la reforma de la vida común y la observancia era difícil de llevar a cabo con el tipo de gobierno delegado del convento. Ello reforzaba nuevamente el poder del Obispo y si bien, como ya se dijo, al comienzo las abadesas lo resintieron, luego lo demandaron para arbitrar los conflictos internos que la reforma producía. Era necesario debilitar el gobierno corporativo para llevar a cabo la reforma y hacer del convento una comunidad de regla y no un cuerpo de Antiguo Régimen. Dicho de otra manera, la reforma separaba lo sagrado de lo profano, lo religioso de lo mundano, lo espiritual de lo temporal.

\section{DE ESPOSAS MÍSTICAS A MADRES SOCIALES}

Los monasterios femeninos como modelo religioso de la sociedad decayeron antes en el mundo que en sus claustros. No tenían cómo mantener su forma de vida tradicional, que se había alimentado finalmente del mundo. Su decadencia no es

84 Ibid., Vol. 130, fj. 445.

85 En 1859, el Monasterio Antiguo de Santa Clara tenía 83.785 pesos en capitales a rédito y los intereses eran de 3.683 pesos. En la década del 60, Santa Rosa gastó 30.000 en reparaciones del convento, sin tocar su capital. Ibid., Vol. 133, fj. 14. 
una señal de descristianización, pues el número de religiosas creció considerablemente en el siglo ${ }^{86}$. Es señal de una transformación en las formas de piedad, propia de un proceso de secularización que separaba lo profano de lo religioso y otorgaba a la religión una dimensión más intramundana dentro del propio catolicismo. Era una convergencia entre el Estado liberal y la jerarquía eclesiástica, sobre la necesidad, en el lenguaje del primero, de que las religiosas fueran útiles a la sociedad y, en el lenguaje eclesiástico, de evangelizar a las mujeres y a los pobres en un contexto de embate laicista. Fue la contemplación como ideal religioso la que vivió una transformación, lo que se expresó en el caso americano exclusivamente en las mujeres. El Estado, la jerarquía eclesiástica y ellas mismas lo percibieron con claridad. Primero lo manifestó el Estado, cuando en 1838 llegó al puerto de Valparaíso un pequeño grupo de religiosas francesas de los Sagrados Corazones. Venían directamente de Picpus, el nombre con que se las conocía por el lugar del convento en París, llamadas por un sacerdote de su misma congregación que, después de que su barco encallara en Chile, se había quedado a contribuir en la labor pastoral. Traer una congregación femenina dedicada a la enseñanza contaba con la aprobación y el entusiasmo de las autoridades civiles y eclesiásticas, aunque no sabían con claridad cómo era. El ministro Mariano Egaña, que hemos visto tras la reforma de regulares en las décadas del 20 y 40, mandó órdenes al gobernador del puerto que reflejan en forma extraordinaria su dureza regalista e ilustrada:

"Ha llegado a noticias del gobierno que han desembarcado en ese puerto algunas damas francesas con el objeto de establecer según se dice un monasterio en Valparaíso. Con tal motivo ha acordado el Presidente de la República que prevenga a dichas damas [...] que conforme a las leyes nacionales no puede establecerse en el territorio de la República convento alguno o casa religiosa [...] sin especial servicio del Supremo Gobierno [...] y que si su objeto fuere promover o fundar algún establecimiento de esta clase deben incurrir a impetar el correspondiente permiso exponiendo los fines que se propone como la dotación con que cuentan los ejercicios a que se dediquen [...]".

El sacerdote le respondió que serían de gran utilidad pues eran enseñantes. A vuelta de correo el Presidente de la República las autorizó, felicitándolas de que estuvieran en el país para llevar a cabo tan loable "proyecto filantrópico" 87 . Fue el comienzo del arribo de las congregaciones apostólicas femeninas. El Arzobispo, con bastante más tristeza que Egaña, sostenía dos décadas más tarde que "[...] en estos tiempos los monasterios de vida contemplativa son mirados de reojo, al paso que, por el contrario, son protegidos con mayor agrado aquellos que de la sociedad

86 Las religiosas de congregaciones apostólicas canalizaron las vocaciones femeninas del siglo, aumentando considerablemente. Entre 1844 y 1899 crecieron de 29 a 1.369 , es decir, 47 veces. Sol Serrano (ed.), Vírgenes viajeras, Santiago de Chile, Ediciones Universidad Católica, 2000, 101.

87 Archivo de los Sagrados Corazones en Santiago de Chile, 4 de septiembre de 1838. Sin clasificar. 
civil puede obtener conveniencias temporales, o, como dicen, más beneficios públicos [...]"88. También ellas sabían que vivían, en sus propias palabras, "amenazas externas". Cuando los primeros gobiernos republicanos les exigieron abrir escuelas se negaron, porque significaba una relación externa con el mundo que no estaban dispuestas a aceptar. La educación, mal que mal y a su manera, la realizaban dentro del convento. Sin embargo más tarde, hacia 1868, el convento de Santa Rosa destinó mil pesos para ese objeto:

"lo que más nos interesa es evitar la ofensa de Dios y que no cundan las escuelas de los masones que ya tienen varias, por eso es preciso cundir las escuelas de nuestra religión para que haigan [sic] buenas Madres de familias y críen a sus hijos en el temor de Dios y esto no se conseguiría con escuelitas de mala muerte" 89 .

Aunque estaban más abiertas al mundo, no era ese su carisma. Ese era el de las congregaciones apostólicas.

Las diferencias entre conventos contemplativos y congregaciones apostólicas son múltiples. Es el paso de una institución corporativa a una institución jerárquica, pues si bien las apostólicas dependían canónicamente del prelado local, dependían en realidad de la madre superiora, que gobernaba una institución centralizada y uniforme donde quiera que estuviera. Es el paso de una economía espiritual a una de servicios, pues las congregacionistas vivían de su trabajo; la dependencia de los vínculos con la sociedad pasa a ser mediada y regulada por poderes centrales; la reunión de mujeres consagradas y seglares se escinde, pues las modernas vivían una estricta clausura y las seglares eran el objeto de su servicio fuera del convento, no dentro de él. Ambas eran instituciones igualmente jerárquicas, tanto en el gobierno como socialmente, en la distribución de los oficios. Si el convento tenía una jerarquía corporalmente integrada, aquella la tenía segregada. En fin, las comparaciones son muchas, pero es necesario hacer la que no se ha hecho: su diferencia como mujeres. Las contemplativas no eran madres, no eran el arquetipo de la "madre educadora", esa capaz de formar la "madre nueva" propia del siglo XIX, aquella que, "primero en el corazón de los hijos y luego en el de los hombres, desarrolla y fortalece las virtudes sociales e individuales" 90 . Aquellas que deben ser esposas, madres, ecónomas y encargadas de la eficiencia doméstica ${ }^{91}$. Las congregacionistas también eran vírgenes y esposas, pero eran madres que formaban a las otras madres, que reformaban a las caídas, protegían a las vulnerables para reintegrarlas a la sociedad, cuidaban a los

88 Mons. Rafael Valentín Valdivieso, 13 de septiembre de 1853, en Fernando Retamal Fuentes, Chilensia Pontificia. Monumenta Ecclesiae Chilensia, Vol. 1, Tomo I, Santiago de Chile, Ediciones Universidad Católica de Chile, 1998, 515.

89 AAS. FG, Vol. 128, fj. 88.

90 Michela di Giorgio, "El modelo católico", en Georges Duby y Michell Perrot, Historia de las mujeres, Tomo 4: El siglo XIX, Barcelona, Taurus, 2000, 183.

91 Dominique Julia, Les trois couleurs du tableau noir: la Revolution, París, Éditions Belin, 1981,68 . 
enfermos y a los niños abandonados. Por eso, cuando los conventos fueron suprimidos en Francia y en México, las hospitalarias fueron mantenidas.

El caso chileno fue más suave y benévolo. Los conventos contemplativos se redujeron a sus propias comunidades y disminuyeron de 300 a 200 entre los años 1844 y $1899^{92}$. No tuvieron problemas con sus bienes, puesto que la Constitución reconoció el derecho de propiedad de las comunidades, y fueron particularmente protegidas por el Código Civil promulgado en 1857, según el cual todos los lugares de culto pasaban a ser regidos por el derecho canónico. Esa fue su protección. No el derecho individual de libertad de asociación.

El ocaso de la clausura se inserta finalmente en un problema político mayor, que es el modelo femenino como madre de la familia. Así la quiere y así la necesita el Estado liberal y la Iglesia ultramontana. La esposa mística podía ser suprimida en un Estado liberal regalista. Los votos perpetuos que fundaban la vida monástica femenina no fueron protegidos por las garantías individuales constitucionales, sino por el derecho canónico incorporado al civil. El Estado liberal regalista impulsó la utilidad social de la religión y esa utilidad social tenía una dimensión de género: las esposas místicas no eran mujeres y por ello fueron reemplazadas por las madres sociales. Quizás por eso el ocaso de la clausura y su relación con la formación del Estado liberal ha sido esquivo para la historiografía política, religiosa y de género.

92 Serrano, op. cit., 101-103. 
